Research Article

\title{
Removal of Sulfide and COD from a Crude Oil Wastewater Model by Aluminum and Iron Electrocoagulation
}

\author{
K. I. Dermentzis ${ }^{1,2}$ \\ ${ }^{1}$ Laboratory of General and Physical Chemistry, Department of Petroleum and Mechanical Engineering, Eastern Macedonia and \\ Thrace Institute of Technology, EMaTTech, 65404 Agios Loukas, Kavala, Hellas \\ ${ }^{2}$ Hephaestus Advanced Research Laboratory, Eastern Macedonia and Thrace Institute of Technology, EMaTTech, 65404 Agios Loukas, \\ Kavala, Hellas
}

Received 21 February 2016; Accepted 11 April 2016

\begin{abstract}
The treatment of petroleum wastewater was studied using the electrocoagulation process with aluminum and iron electrodes aiming to simultaneous removal of sulfide and COD. All affecting parameters, such as solution $\mathrm{pH}$, applied current density, time of electroprocessing, electrode material and addition of surfactant, were investigated. Sulfide was rapidly and effectively removed using iron electrodes. The removal of COD was effectively effectively enhanced by performing the electrocoagulation process after addition of the surfactant polyethylene glycol oleate.
\end{abstract}

Keywords: electrochemical coagulation, petroleum wastewater, sulfide, COD, surfactant

\section{Introduction}

The petroleum refinery industry generates large volumes of wastewaters which contain sulfides (hydrogen sulfide, sodium sulfide and ammonium sulfide) and chemical oxygen demand (COD) originated from phenols, oils and grease. Dependent on the solution $\mathrm{pH}$, hydrogen sulfide is found in equilibrium with sulfide ions, $\mathrm{HS}^{-}$and $\mathrm{S}^{2-}$. Because of the higher reduction state of sulfur, hydrogen sulfide and sulfide ions need increased amounts of oxygen demand $\left(2\right.$ moles $\mathrm{O}_{2}$ $/$ mole $\mathrm{S}^{2-}$ ) resulting in depletion of oxygen in aquatic systems where they are discharged and the threat of fish life. Problems related to sulfide buildup are: safety hazards to sewer employees due to the high toxicity of the gaseous hydrogen sulfide, release of obnoxious odors to the urban atmosphere, corrosion of concrete sewer pipes, negative impacts on the subsequent biological treatment or the transfer of oxygen in biological processes and poisoning of catalysts used by the downstream refinery sector. The concentration of sulfide in petroleum refinery wastewater ranges between $2-10 \mathrm{mg} / \mathrm{L}$, in crude oil treatment wastewater between $60-80 \mathrm{mg} / \mathrm{L}$, while in tannery effluents it can exceed $200 \mathrm{mg} / \mathrm{L}$. The permissible limit for fresh or salt water fish is $0.5 \mathrm{mg} / \mathrm{L}[1,2]$.

The traditional treatment of petroleum refinery wastewater for the removal of sulfide involves direct air stripping, oxidation, chemical precipitation [2] and biological treatment [3]. Hydrocarbons and other organics present in the petroleum refinery wastewater are removed by biological treatment, activated sludge adsorption, solvent extraction, photo-degradation, Fenton and photo-Fenton processes, flocculation/ceramic membrane filtration, chemical coagulation-precipitation and electrochemical processes, such as electrooxidation, electro-Fenton and

\footnotetext{
*E-mail address: demerz@otenet.gr ISSN: 1791-2377@ 2016 Eastern Macedonia and Thrace Institute of Technology. All rights reserved.
}

electrocoagulation [4-6]. Chemical coagulation is a quite effective method for treating industrial wastewaters, but may induce secondary pollution by adding coagulants, such as aluminum or iron salts or organic poly-electrolytes to remove colloidal matter as gelatinous hydroxides.

Electrocoagulation uses no chemicals as coagulating agents. These are generated during the electrolysis process by electro-dissolution of a sacrificial anode made of aluminum or iron. The main reactions occurring during electrocoagulation with aluminum and iron electrodes produce aluminum and ferrous or ferric ions respectively at the sacrificial anode (reactions 1-3) and hydroxide ions as well hydrogen gas at the cathode (reaction 4):

$$
\begin{array}{ll}
\mathrm{Fe} \rightarrow \mathrm{Fe}^{2+}+2 \mathrm{e} & \text { anode } \\
\mathrm{Fe} \rightarrow \mathrm{Fe}^{3+}+3 \mathrm{e} & \text { anode } \\
\mathrm{Al} \rightarrow \mathrm{Al}^{3+}+3 \mathrm{e}^{-} & \text {anode } \\
2 \mathrm{H}_{2} \mathrm{O}+2 \mathrm{e}^{-} \rightarrow 2 \mathrm{OH}^{-}+\mathrm{H}_{2} & \text { cathode }
\end{array}
$$

The anodically produced $\mathrm{Fe}^{2+}, \mathrm{Fe}^{3+}$ and $\mathrm{Al}^{3+}$ ions combine with the cathodically produced $\mathrm{OH}^{-}$ions forming the known coagulants $\mathrm{Fe}(\mathrm{OH})_{2}, \mathrm{Fe}(\mathrm{OH})_{3}$ and $\mathrm{Al}(\mathrm{OH})_{3}$ according to reactions (5) - (7):

$$
\begin{aligned}
& \mathrm{Fe}^{2+}+2 \mathrm{OH}^{-} \rightarrow \mathrm{Fe}(\mathrm{OH})_{2} \\
& \mathrm{Fe}^{3+}+3 \mathrm{OH}^{-} \rightarrow \mathrm{Fe}(\mathrm{OH})_{3} \\
& \mathrm{Al}^{3+}+3 \mathrm{OH}^{-} \rightarrow \mathrm{Al}(\mathrm{OH})_{3}
\end{aligned}
$$

The iron and aluminum hydroxide flocs act as coagulants and absorbents for particulates. Both phenomena act synergistically leading to a rapid removal of pollutants from water. 
Electrocoagulation has been successfully performed for decolorization treatment of dyes and remediation of dyehouse wastewaters [7,8], treatment of oil wastes [9], diesel and bio-diesel wastewaters [10], tannery effluents [11], fluoride containing waters [12] and heavy metal bearing effluents $[13,14]$.

In spite of abundant applications of electrocoagulation for the treatment of various kinds of wastewater, its use for the treatment of crude oil wastewater is scarce in literature [15]. This paper reports the efficiency of the electrocoagulation process with aluminum and iron electrodes in removing both, sulfide and COD simultaneously from petroleum wastewater. All parameters affecting the process efficiency are investigated, such as electrode nature, applied current density, solution $\mathrm{pH}$, addition of surfactant and electroprocessing time. In addition, the mass loss of anodes and the electrical energy consumption are determined.

\section{Materials and Methods}

\subsection{Materials}

All chemicals, polyethylene glycol oleate (PEGO), $\mathrm{Na}_{2} \mathrm{~S} \theta 9 \mathrm{H}_{2} \mathrm{O}, \mathrm{Na}_{2} \mathrm{SO}_{4}, \mathrm{NaCl}, \mathrm{NaOH}, \mathrm{H}_{2} \mathrm{SO}_{4}$ are of analytical grade (Merck). The solution $\mathrm{pH}$ is adjusted, when needed, by addition of appropriate amounts of $0.1 \mathrm{M} \mathrm{NaOH}$ and $0.1 \mathrm{M}$ $\mathrm{HCl}$ solutions.

The crude oil wastewater model was prepared by mixing appropriate amounts of $\mathrm{Na}_{2} \mathrm{~S} \theta 9 \mathrm{H}_{2} \mathrm{O}$ and heating oil with fresh water and separating the aqueous from the oily phase in a separation funnel. In the treated solution $2 \mathrm{~g} / \mathrm{L} \mathrm{Na}_{2} \mathrm{SO}_{4}$ is added for increasing the conductivity and, therefore, reducing the electrical energy consumption. The main characteristics of the prepared oily wastewater are: sulfide $80 \mathrm{mg} / \mathrm{L}, \mathrm{COD}$ $600 \mathrm{mg} / \mathrm{L}$, conductivity $4000 \mu \mathrm{S} / \mathrm{cm}$ and $\mathrm{pH}$ 7.5. The total COD of the oily wastewater originates from COD of the organic water soluble petroleum components and COD of sulfide ions.

\subsection{Typical experimental procedure}

Electrolyses were conducted at room temperature in a cylindrical glass cell of $500 \mathrm{ml}$ in which aliquot solutions of $250 \mathrm{ml}$ were placed and slowly stirred with a magnetic bar at $500 \mathrm{rpm}$. A laboratory model DC power supply apparatus (Agilent E3612A, USA) was used to maintain constant DC voltage and current. Conductivity was measured by means of a conductometer (inoLab Cond. Level 1, WTW). The pH and the temperature were measured using a Hanna (HI8314) $\mathrm{pH}$ meter connected to a temperature sensor (HI1217D). The electrocoagulation treatment is followed by concentration measurements of sulfide and COD. The concentration of sulfide was determined by UV-Vis spectrophotometry (HITACHI U-2000, Japan) and the COD by a COD reactor (Thermoreaktor TR 420, MERCK) and a direct reading spectrophotometer (Spectroquant Pharo100, MERCK). Three commercially obtained aluminum or iron plates of size $10 \mathrm{~cm}$ $x 5 \mathrm{~cm} \times 0.2 \mathrm{~cm}$ immersed to a $6 \mathrm{~cm}$ depth with an effective area of $30 \mathrm{~cm}^{2}$ each, were used as electrodes in the experiments. The inter-electrode distance was $1.5 \mathrm{~cm}$. To remove the oxide and passivation layer from aluminum and iron surface the electrodes were grinded with sandpaper and activated by dipping them in $5 \mathrm{~N} \mathrm{HCl}$ for 1 minute. $0.5 \mathrm{~g} \mathrm{KCl}$ was added to every treated solution. The added $\mathrm{KCl}$ serves for prevention of passivation on the anode surface and decrease of the excessive ohmic drop in the solution. The polarity of the cell was reversed every 30 minutes to limit the formation of the passivation layers on the electrodes. Samples were extracted every 2 or 10 minutes, left to sedimentation for 24 hours, filtered using Whatman filter paper (Grade 40) and brought to analysis.

\section{Results and Discussion}

\subsection{Effect of electrode material}

The initial solution $\mathrm{pH}$ of 7.5 needed no adjustment, as it lies near the neutral region which is the optimal region for performing the electrocoagulation treatment. The coagulants $\mathrm{Al}(\mathrm{OH})_{3}, \mathrm{Fe}(\mathrm{OH})_{2}$ and $\mathrm{Fe}(\mathrm{OH})_{3}$ are effective in the near neutral region. In stronger acidic solution they lie in form of $\mathrm{Al}^{3+}, \mathrm{Fe}^{2+}$ and $\mathrm{Fe}^{3+}$ cations and in stronger alkaline solution partially in form of anionic hydroxo-complexes $\mathrm{Al}(\mathrm{OH})_{4}{ }_{4}$, $\mathrm{Fe}(\mathrm{OH})_{3}{ }^{-}, \mathrm{Fe}(\mathrm{OH})_{4}{ }^{-}$. These cationic and anionic species do not favour the coagulation process. The value of $\mathrm{pH}$ does not change markedly during the electrocoagulation process, because the cathodically produced $\mathrm{OH}^{-}$ions combine with the anodically produced $\mathrm{Al}^{3+}, \mathrm{Fe}^{2+}$ and $\mathrm{Fe}^{3+}$ ions and precipitate as insoluble metal hydroxides [16-18].

Figure 1 illustrates the removal of sulfide over time of electroprocessing, where the treatment is conducted with different electrodes of iron and aluminum and constant applied current density of $2.5 \mathrm{~mA} / \mathrm{cm}^{2}$. The removal of sulfide with aluminum electrodes is low and very slow $(<6 \%)$. On the contrary, sulfide is quickly and completely removed with iron electrodes (>99\%). Bivalent $\mathrm{Fe}^{2+}$ ions combine with $\mathrm{H}_{2} \mathrm{~S}$ and sulfide ions ( $\mathrm{HS}^{-}$and $\mathrm{S}^{2-}$ ) to form insoluble precipitates, according to reactions (8-10):

$$
\begin{aligned}
& \mathrm{Fe}^{2+}+\mathrm{H}_{2} \mathrm{~S} \rightarrow \mathrm{FeS}_{(\mathrm{S})}+2 \mathrm{H}^{+} \\
& \mathrm{Fe}^{2+}+2 \mathrm{HS}^{-} \rightarrow \mathrm{Fe}(\mathrm{HS})_{2(\mathrm{~S})} \\
& \mathrm{Fe}^{2+}+\mathrm{S}^{2-} \rightarrow \mathrm{FeS}_{(\mathrm{S})}
\end{aligned}
$$

Ferric ions, $\mathrm{Fe}^{3+}$, also remove sulfide by oxidizing them to elemental sulfur, according to reaction (11).

$$
2 \mathrm{Fe}^{3+}+\mathrm{S}^{2-} \rightarrow 2 \mathrm{Fe}^{2+}+\mathrm{S}_{(\mathrm{S})}^{0}
$$

The produced $\mathrm{Fe}^{2+}$ ions capture other sulfide ions, according to above stated reactions (8-10).

Corresponding reactions between $\mathrm{Al}^{3+}$ and sulfide ions do not exist. Consequently, since iron electrodes are by far more effective in reducing sulfide, all subsequent experiments were conducted using iron electrodes

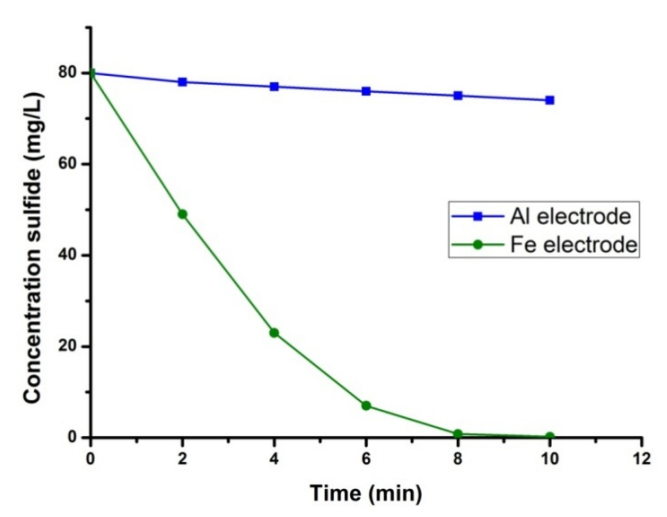

Fig. 1. Concentration variation of sulfide with electroprocessing time using $\mathrm{Al}$ and Fe electrodes and constant current density of $2.5 \mathrm{~mA} / \mathrm{cm}^{2}$ 
Figure 2a shows the removal of COD of the oily wastewater during the electrocoagulation treatment with $\mathrm{Al}$ and Fe electrodes. After 60 minutes of electrolysis the initial COD of $600 \mathrm{mg} / \mathrm{L}$ was slightly reduced to 561 and $382 \mathrm{mg} / \mathrm{L}$, i.e. by only $6 \%$ and $36 \%$ for $\mathrm{Al}$ and $\mathrm{Fe}$ electrodes respectively. Based on the experimental results, it can be concluded that the electrocoagulation treatment is not effective for the removal of dissolved oily pollutants and COD even at higher current densities and prolonged duration of electroprocessing.

\subsection{Effect of surfactant addition}

COD could more drastically be reduced by performing the electrocoagulation treatment after addition of the non ionic surfactant polyethylene glycol oleate (PEGO). Also the anionic surfactant sodium dodecyl sulfate (SDS) was used with comparable similar effectiveness. As well known, the surfactant molecules with their organic sides surround the oil droplets forming oil-surfactant adducts and micelles. Surfactants show higher affinity for adsorption on the coagulants $\mathrm{Fe}(\mathrm{OH})_{3}$ or $\mathrm{Al}(\mathrm{OH})_{3}$ and so do the oil-surfactant adducts and micelles. Therefore, the oil molecules are swept by the surfactant molecules and removed together from the treated solution. By adding $320 \mathrm{mg} / \mathrm{L}$ of the surfactant PEGO the solution COD of $600 \mathrm{mg} / \mathrm{L}$ initially increases to 1200 $\mathrm{mg} / \mathrm{L}$. However, faster and more effective removal of the total COD occurs. Under the same conditions of applied current density and electroprocessing time, the total COD of 1200 $\mathrm{mg} / \mathrm{L}$ (originated from oil and added surfactant) decreased to 356 and $198 \mathrm{mg} / \mathrm{L}$, showing a reduction of about 70 and $85 \%$ using aluminum and iron electrodes respectively (Figure 2a,b). During the electrocoagulation process the petroleum hydrocarbons are not oxidized or destructed. They are adsorbed and relocated as a whole in the electro-generated $\mathrm{Al}(\mathrm{OH})_{3}$ or $\mathrm{Fe}(\mathrm{OH})_{3}$ precipitate or rise to the surface by electroflotation, due to the electrochemically in situ generated hydrogen bubbles.

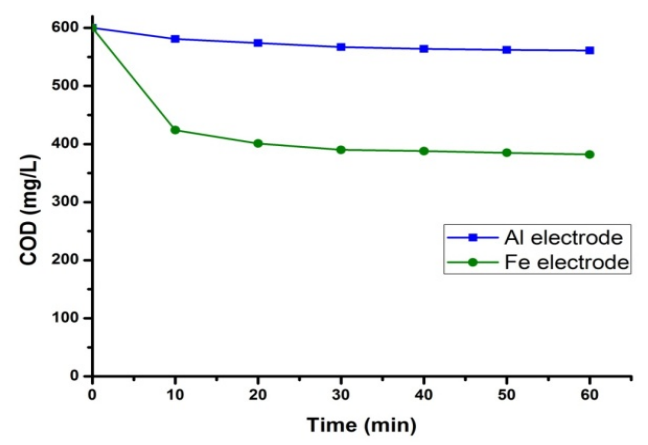

a)

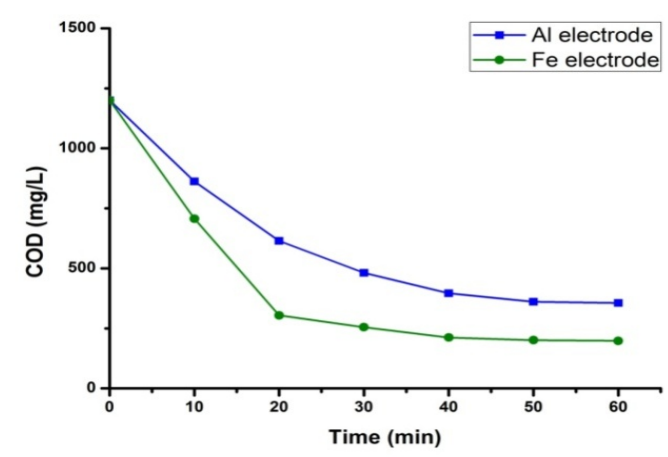

b)

Fig. 2a,b. Electrocoagulation treatment for $\mathrm{COD}$ removal with $\mathrm{Al}$ and $\mathrm{Fe}$ electrodes

a) without addition b) with addition of surfactant

\subsection{Effect of applied current density}

It is well known that the applied current density determines the dosage rate and the flocs growth and size of the anodically produced coagulant resulting in a faster removal of pollutants. Electrocoagulation experiments with iron electrodes were conducted at current densities $2.5,5$ and $10 \mathrm{~mA} / \mathrm{cm}^{2}$, constant sulfide concentration $80 \mathrm{mg} / \mathrm{L}$, COD $1200 \mathrm{mg} / \mathrm{L}$ and initial solution $\mathrm{pH}$ 7.5. According to Figure 3, the removal efficiency of sulfide increases, as anticipated, with increasing current density. For the three applied current densities of 2.5, 5 and $10 \mathrm{~mA} / \mathrm{cm}^{2}$, the initial sulfide concentration of $80 \mathrm{mg} / \mathrm{L}$ was reduced under the permissible limits $(0.5 \mathrm{mg} / \mathrm{L})$ in 10,6 and 4 minutes of electrolysis time.

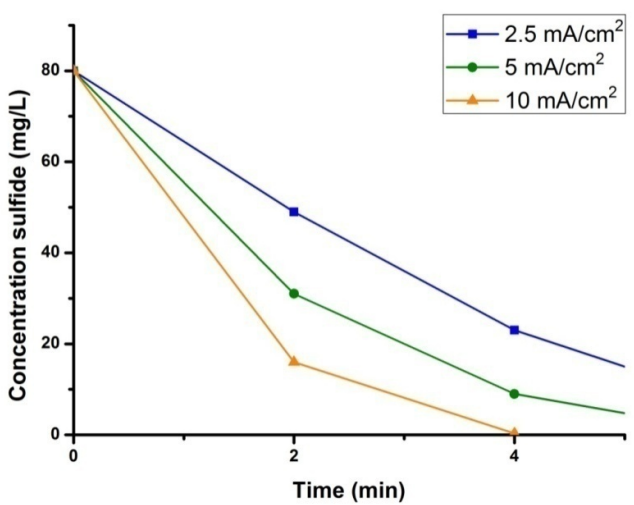

Fig. 3: Residual concentration of sulfide versus electrolysis time and applied current density

Similarly, according to Figure 4, the removal of COD also increases with increasing current density, as it falls under 200 $\mathrm{mg} / \mathrm{L}$ from its initial value of $1200 \mathrm{mg} / \mathrm{L}$ in 60,40 and 30 minutes for the three applied current densities of 2.5, 5 and 10 $\mathrm{mA} / \mathrm{cm}^{2}$, respectively.

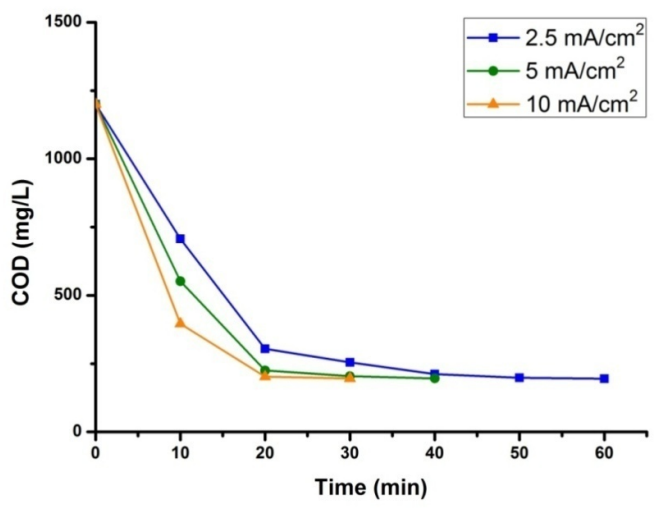

Fig. 4. Residual concentration of COD versus electrolysis time and applied current density

\subsection{Economic evaluation}

The economic study comprises the electrical energy consumption, the electrode mass loss and the sludge disposal. The cost of iron electrode is $1 € / \mathrm{Kg}$, with an electrical energy of $0.06 € / \mathrm{kWh}$ and a sludge disposal of $0.015 € / \mathrm{Kg}$.

The electrical energy consumption for removal of sulfide and COD (in the presence of surfactant) is calculated from Equation 1: 


$$
E=\frac{U \cdot I \cdot t}{V}
$$

$\left[E=\right.$ electrical energy consumption $\left(\mathrm{kWh} / \mathrm{m}^{3}\right), U=$ applied voltage $(\mathrm{V}), I=$ current intensity $(\mathrm{A}), t=$ electrolysis time (h) and $V=$ solution volume (L)].

The mass loss of iron electrode $M_{F e}$ is calculated from Faraday low (Equation 2):

$$
M_{F e}=\frac{I \cdot t \cdot M}{z \cdot F \cdot V}
$$

$[I=$ current intensity (A), $t=$ time of electrolysis (s), $M$ $=$ Molecular mass of iron $(\mathrm{g} / \mathrm{mol}), z=$ number of changeable electrons, $F=$ Faraday constant $(96485 \mathrm{Cb} / \mathrm{mol}), V=$ solution volume (L)].

From all the above mentioned, it follows that the electrocoagulation method needs for a complete removal of $80 \mathrm{mg} / \mathrm{L}$ sulfide from $1 \mathrm{~m}^{3}$ wastewater: $0.22 \mathrm{Kg}$ of iron, 0.38 $\mathrm{kWh}$ electrical energy, where $0.45 \mathrm{Kg}$ of sludge is produced. Thus, the total cost for the electrocoagulation treatment is calculated to $0.25 € € / \mathrm{m}^{3}$ of treated wastewater. Electrocoagulation seems more advantageous over the classical chemical coagulation, where $0.31 \mathrm{Kg}$ of coagulant
$\mathrm{FeCl}_{3} .6 \mathrm{H}_{2} \mathrm{O}$ is needed, $0.47 \mathrm{Kg}$ of sludge is produced and 0.36 $€ / \mathrm{m}^{3}$ of treated wastewater is calculated.

\section{Conclusions}

The simultaneous removal of sulfide and COD from a crude oil wastewater model using electrocoagulation with iron electrodes is possible. The removal rate increases with increasing current density. The treatment with iron electrodes of the crude oil wastewater containing $80 \mathrm{mg} / \mathrm{L}$ sulfide led to a complete reduction of sulfide under the admissible limits at applied current densities $2.5,5$ and $10 \mathrm{~mA} / \mathrm{cm}^{2}$ and electrolysis time 10, 6 and 4 minutes respectively. The removal of $\mathrm{COD}$ is low for both, iron and aluminum electrodes respectively. However, COD can more effectively be reduced by performing the process after addition of the surfactant polyethylene glycol oleate. Thus, COD decreases by about 36 and $67 \%$ for the corresponding surfactant free and surfactant aided electrocoagulation treatment. The total electrocoagulation treatment cost of a crude oil wastewater model containing $80 \mathrm{mg} / \mathrm{L}$ sulfide and $600 \mathrm{mg} / \mathrm{L}$ COD amounts to $0.25 € / \mathrm{m}^{3}$. The proposed electrochemical process is a safe and economical method for removal of toxic pollutants, such as sulfide and COD from industrial petroleum wastewater.

\section{References}

1. L. Altas, H. Büyükgüngör, J. Hazard. Mater., 153, $462-469$ (2008).

2. S.W. Poulton, M.D. Krom, J.V. Rijn, R. Raiswell, Water Res. 36, 825-834 (2002).

3. E. Vaiopoulou, P. Melidis, A. Aivasidis, Water Res. 39, 4101-4109 (2005).

4. S.A. Martinez-Delgadillo, M.A. Morales-Mora, I.D. BarceloQuintal, Sustain. Environ. Res., 20, 227-231 (2010).

5. D. Bhagawan, S. Poodari, S. Golla, V. Himabindu, S. Vidyavathi, Des. Water Treat., 57, 3387-3394 (2016).

6. O. Sahu, B. Mazumdar, P.K. Chaudhari, Environ. Sci. Poll. Res., 21, 2397-2413 (2014).

7. V. Khandegar, K. Saroha, J. Environ. Manage. 128C 949-963 (2013).

8. K. Dermentzis, D. Marmanis, E. Valsamidou, A. Christoforidis, K. Ouzounis, Environ. Eng. Manage.J., 10, 1703-1709 (2011).

9. U.T. Un, S. A. Koparal, U.B. Ogutveren, J. Environ. Manage., 90, 428-433 (2009).

10. O. Chavalparit, M. Ongwandee, J. Environ. Sci., 21, 1491-1496 (2009).
11. Ö. Apaydin, U. Kurt, M.T. Gönullü, Global Nest J., 11, 546-555 (2009).

12. N. Drouiche, S. Aoudj, H. Lounici, H. Mahmoudi, N. Ghaffour, M.F.A. Goosen, Desal. Water Treat. 29, 96-102 (2011).

13. M. Kobya, N. Erdem, E. Demirbas, Desal. Water Treat. DOI: 10.1080/19443994.2014.951692 (2014) .

14. K. Dermentzis, D. Marmanis, A. Christoforidis, A. Moumtzakis, Desal. Water Treat., DOI: 1080/19443994.2014.950992 (2014).

15. M.S. Secula, I. Cretescu, S. Petrescu, Environ. Eng. Manage. J., 11, 1485-1491 (2011).

16. D. Stergiopoulos, K. Dermentzis, P. Giannakoudakis, S. Sotiropoulos, , Global NEST J., 16, 499-506 (2014).

17. N. Adhoum, L. Monser, N. Bellakhal, J-E. Belgaied, J. Hazard. Mater. B112, 207-213 (2004).

18. H. Binder, H. Loos, K. Dermentzis, H. Borrmann, A. Simon, Chemische Berichte 124, 427-432 (1991). 